BLS 34, No 1 2008. DOI: http://dx.doi.org/10.3765/bls.v34i1.3556

(published by the Berkeley Linguistics Society and the Linguistic Society of America)

\title{
GIVE Verb-Object Constructions in French: from Grammar to Idioms
}

\author{
MYRIAM BOUVERET \\ University of Rouen-University of California, Berkeley ${ }^{l}$
}

\section{Introduction}

This paper presents a corpus-based study of French verb-object constructions headed by donner 'give'. ${ }^{2}$ Using the Explanatory and Combinatorial Lexicology (ECL) framework part of Meaning Text Theory (Mel'čuk 1997), I combine it with a Construction Grammar model (Kay and Fillmore 1999). I follow Construction Grammar in regarding grammatical constructions and idioms as having equal status as constructs. If constructs are form-meaning mappings then their description will involve both semantic and formal generalizations. The first section analyzes constructions collected from the corpus. The second section discusses the degrees of grammaticalization and idiomaticity of donner verbobject constructions. The particular case of X DONNER $Y+$ INFINITIVE (' $\mathrm{X}$ give $\mathrm{Y}$ to be V-ed') is studied in the third section, where I further examine the notions of construction, construct and cognitive salience. This construction is particularly interesting in its fully compositional relationship to non-literal and highly idiomatic subconstructions.

\section{GIVE Verb-Object Constructions in the Frantext Corpus}

\subsection{Frequencies}

The donner transitive construction is widely polysemous, meaning 'give' ( $\mathrm{V}+$ concrete things or any other $X$ CAUSE $Z$ TO RECEIVE $Y$ construction), 'make' (V+communication nouns), 'organize' (V+event nouns), 'show' (V+leading situation), 'serve' ( $\mathrm{V}+$ food nouns). Corpus results are summarized in Table $1:^{3}$

\footnotetext{
${ }^{1}$ This paper was written while the author was a visiting scholar at the Department of Linguistics, University of California, Berkeley. Special thanks to Eve Sweetser for her many suggestions and to Charles J. Fillmore for his reading and comments on an earlier draft.

${ }^{2}$ Base textuelle Frantext, ATILF-CNRS, University of Nancy, France. Literature corpus. Period consulted 1980-2000.

${ }^{3}$ Although covering 20 years from 1980 to 2000, the corpus search does not provide all the transitive meanings of the verb.
} 
Myriam Bouveret

Table 1: DONNER Transitive Constructions in Frantext Corpus 1980-2000

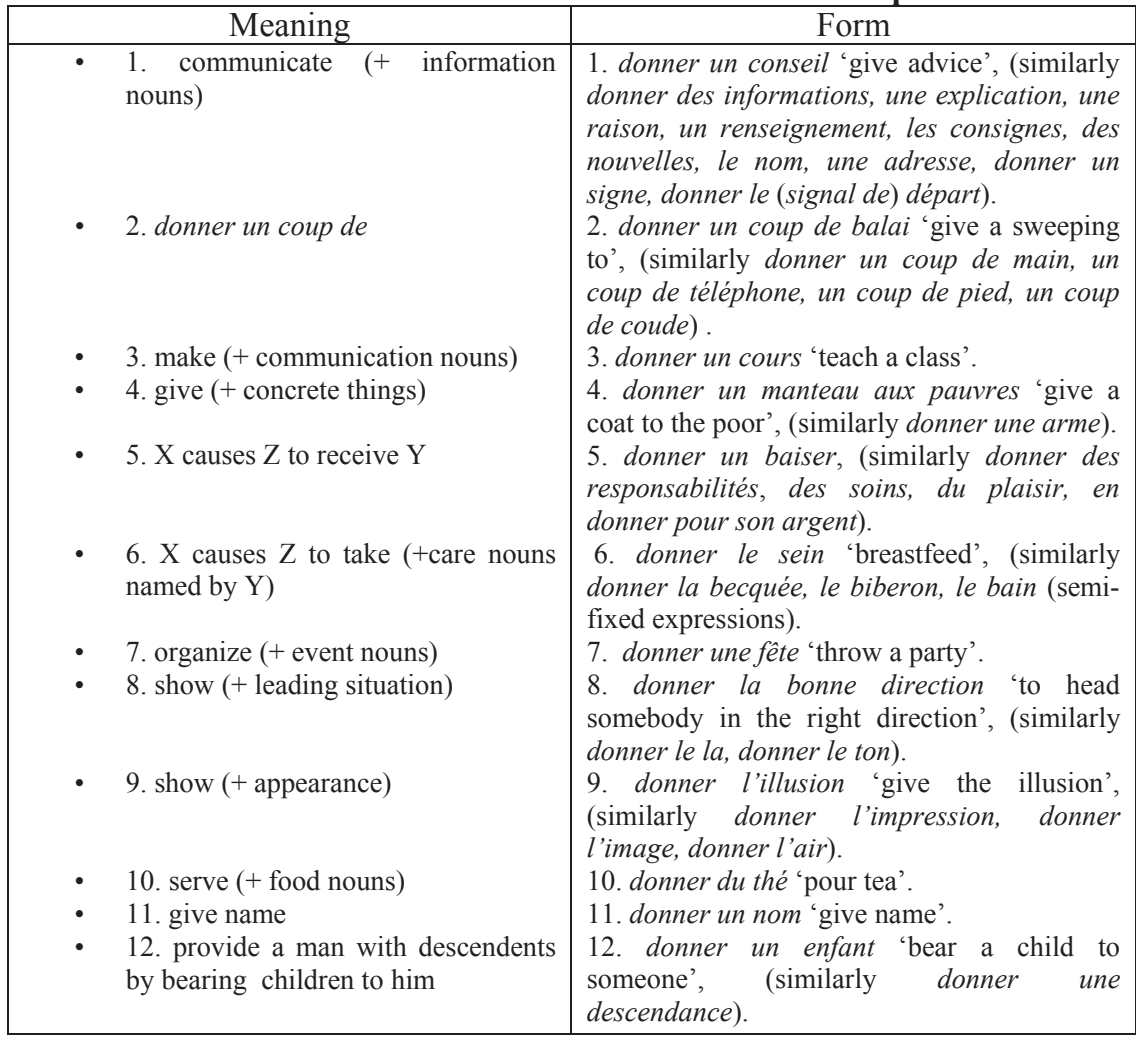

Argument structure and the deep semantic nature of constructions vary and donner can express different event types including a simple or complex causedmotion construction (donner un manteau aux pauvres 'give a coat to the poor'), a resultative construction (donner un nom 'give a name', donner la chair de poule 'give goose pimples', donner le vertige 'make feel dizzy', donner un coup de pied 'give a kick', donner un conseil 'give advice', donner l'assaut 'to assault'), an activity construction (donner une fête 'throw a party', donner un cours 'teach a class'), and a causation construction (donner sa voiture à réparer 'give one's car for repair').

In the corpus, donner as a support verb is the most frequent construction (23\%) where it collocates with: nom 'name', instructions 'instruction', explication 'explanation', conseil 'advice', ordre 'order', baiser 'kiss', nouvelles 'news', conference 'conference', cours 'class', etc... (similarly donner un conseil 'give advice', des informations 'give informations', une explication 'give an explanation', un renseignement 'give an information', les consignes 'give instructions' (1), donner un coup de balai 'give a sweeping to', un coup de main 


\section{GIVE Verb-Object Constructions in French from Grammar to Idioms}

'give a hand', un coup de téléphone 'give a call', un coup de pied 'give a kick', un coup de coude 'give somebody a nudge' (2), donner un cours 'teach a class' (3), donner un nom 'give a name' (11) in Table 1). The second corpus (Word Sketch Engine Google corpus) shows $30 \%$ of donner as a support verb whereas the third corpus (Le Monde 2002) has $12 \%$ of support verb constructions.

In comparison, the concrete meaning of donner has a very low frequency in the Frantext corpus (8\%), although in a French dictionary (i.e. Le Nouveau Petit Robert) this sense is presented first in accordance with lexicographic microstructure rules. A search of two other corpora confirms this infrequency, showing 5\% in Le Monde $2002^{4}$ and $0 \%$ in Word Sketch Engine Google corpus. ${ }^{5}$ These results are somehow counter-intuitive given the perception of the concrete meaning of the verb donner as being more central. A cognitive explanation of this centrality could be provided by language acquisition studies:

Children tend to use verbs meaning want, make/do, put, bring, take out or give before other verbs are used. In a longitudinal study Ninio observes that SVO and VO patterns were initially produced with only one or at most a few verbs for a prolonged period. More and more verbs came to be used in an exponentially increasing fashion (...). On both Ninio's account and the present proposal, patterns are learned on the basis of generalizing over particular instances. (Goldberg 2006:78, citing Ninio 1999)

Not all of children's earliest verbs are highly transitive but Goldberg's hypothesis is then that "high frequency of particular verbs in particular constructions facilitates children's unconsciously establishing a correlation between the meaning of a particular verb in a constructional pattern and the pattern itself, giving rise to an association between meaning and form" (Goldberg 2006:79). She concludes with others that "frequency and order of acquisition play key roles in category formation in that training on prototypical instances frequently and/or early facilitates category learning" (Goldberg and Casenhiser 2006:199).

From a lexicographic point of view, the explanation for ranking the concrete meaning first can sometimes--but not always--be etymological. The concrete meaning of donner appears in French during the second half of the tenth century with objects referring to physical gifts (Il lui donna une fort belle dot 'He gave her a fine dowry') then later (1050) in the expression donner l'aumône 'give alms'. Historically, donner appeared first in 842 in Les Serments de Strasbourg, linked to mental attributes like power or strength (ATILF 2007), donner le pouvoir 'empower'.

\subsection{Light Verbs and Support Verbs}

Support verb constructions are a specific type of verb-object construction that are distinguished both lexically and syntactically. In (1), a free construction with a

\footnotetext{
${ }^{4}$ Le Migou search engine, OLST, University of Montréal. Newspaper corpus.

${ }^{5}$ Word Sketch Engine, LEXCOM, Adam Kilgarriff, University of Brighton, UK. Google corpus.
} 


\section{Myriam Bouveret}

plain verb, the verb is the governor and the object book the dependent noun, whereas in (2), a support verb construction, it is the noun kiss that expresses an activity and that bears the arguments Jenny and John.

John gave Theo a book.

(2) Jenny gave John a kiss.

The relationship of support verb constructions to their morphologically related equivalents is unpredictable (as in English kiss, advice, information). The French constructions donner un conseil 'give advice', donner une information 'give information', donner une giffle 'give a slap', and donner une tape 'give a kick' are regularly related to the semantically equivalent verbs conseiller 'advice', informer 'inform', giffler 'slap', taper 'kick'. But there is no verbal form for donner un coup 'give a kick', donner une conférence 'hold a conference', or donner un cours 'teach a class;' and donner un baiser 'give a kiss' only matches the meaning baiser in its old sense 'kiss,' which currently appears in certain fixed expressions. In all of these constructions, donner is a light verb as well as a support verb.

How is a support verb (Gross 1989, 2005, Gross and De Pontonx 2005) different from a light verb? The category of support verb, unlike that of light verb, includes verbs which add meaning to an expression, as in envoyer un baiser 'blow a kiss.' Therefore, the category of support verb is a broader set of verbs; ${ }^{6}$ which includes both (3) and (4), even though (4) is not a light verb because it adds a causative meaning:

L'enfant prend un bain.

'The child is having a bath.'

Only the neutral prendre 'take' in prendre un bain 'take a bath' (3) or the neutral donner in donner un coup 'give a kick' is considered a light verb.

Light verbs are not just light from a semantic point of view but also from a cognitive point of view; giving salience to the frame of the noun as in sentence (2) or (3), whereas a plain verb gives salience to its own verbal frame as in (1) (Bouveret and Fillmore 2008). The same "deferral" of salience occurs with any verb named as a support verb regardless of its additional semantic content or the change in the argument perspective as in (4). We can thus observe that the SUPPORT VERB + NOUN construct gives cognitive salience to the direct object in the transitive construction where the verb stands as syntactically and lexically relevant. This does not imply that the verb is completely semantically empty though, as the choice of the lexical unit is still motivated by some semantic components, part of the polysemy of donner which can be minimally paraphrased by: ' $\mathrm{X}$ causing $\mathrm{Z}$ to have $\mathrm{Y}$ '. But the light verb does not inherit the plain concrete

\footnotetext{
${ }^{6}$ From our ECL framework point of view (cf. Mel’čuk 2005).
} 


\section{GIVE Verb-Object Constructions in French from Grammar to Idioms}

meaning ('transmission of $\mathrm{Y}$ entity from $\mathrm{X}$ to $\mathrm{Z}$ entailing the possession of $\mathrm{Y}$ entity by Z for a certain period of time'), as in Theo gave John a book.

\section{Idiomaticity and Grammaticality: Categories of Constructions and Degrees of Fixity}

\subsection{Constructions and the Idiosyncrasy in a Language}

In a Construction Grammar, constructions are seen as a range of phenomena from fixed expressions to idioms and fully open-slot constructions. Constructions can be grouped into more or less constrained families: N P N, for example, as in Construction after Construction (Jackendoff 2008), or idiomatic questions as in What's $X$ doing $Y$ (Kay and Fillmore 1999). Using the ECL framework and a cline of fixity, I propose to distinguish the following four categories of donner transitive constructions in French:

(A) lexically open constructions (Il donna un manteau au pauvre 'He gave a coat to the poor person').

(B) support verb constructions (Donne-moi ton avis 'Give me your advice').

(C) semi-fixed idioms (Le nouveau gouvernement donne le ton 'The new government shows the way' (literally 'sets the musical pitch')).

(D) idioms (Ce morceau lui donne du fil à retordre 'This piece of music is giving him a hard time' (literally 'gives him rope to twist').

The partition between these categories is based on criteria described in Table 2 as follows:

Criterion 1: pronominalization

Criterion 2: predicate noun allowing verbalization

Criterion 3: article and number variation

Criterion 4: insertion test

Criterion 5: commutation test

Criterion 6: negation test

Criterion 7: zeugma test

Table 2: Classification of DONNER Verb-Object Constructions

\begin{tabular}{|l|c|c|c|c|c|c|l|l|}
\hline $\begin{array}{l}\text { Examples of } \\
\text { Constructions }\end{array}$ & $\begin{array}{c}\text { criterion } \\
\mathbf{1}\end{array}$ & $\begin{array}{c}\text { criterion } \\
\mathbf{2}\end{array}$ & $\begin{array}{c}\text { criterion } \\
\mathbf{3}\end{array}$ & $\begin{array}{c}\text { criterion } \\
\mathbf{4}\end{array}$ & $\begin{array}{c}\text { criterion } \\
\mathbf{5}\end{array}$ & $\begin{array}{c}\text { criterion } \\
\mathbf{6}\end{array}$ & $\begin{array}{l}\text { criterion } \\
\mathbf{7}\end{array}$ & $\begin{array}{l}\text { Category of } \\
\text { construction }\end{array}$ \\
\hline $\begin{array}{l}X \quad \text { donne un } \\
\text { manteau à } Z\end{array}$ & YES & NO & YES & YES & YES & YES & YES & $\begin{array}{l}\text { A: free } \\
\text { construction }\end{array}$ \\
\hline $\begin{array}{l}X \text { donne un } \\
\text { conseil à } Z\end{array}$ & YES & YES & YES & YES & $\begin{array}{c}\text { NO : A } \\
\text { YES : B }\end{array}$ & YES & NO & $\begin{array}{l}\text { B: support } \\
\text { verb } \\
\text { constructions }\end{array}$ \\
\hline $\begin{array}{l}\text { X donne le ton } \\
\text { YES }\end{array}$ & NO & NO & NO & NO & YES & NO & $\begin{array}{l}\text { C : semi-fixed } \\
\text { constuctions }\end{array}$ \\
\hline $\begin{array}{l}\text { X donne du fil à } \\
\text { retordre à Z }\end{array}$ & NO & NO & NO & NO & NO & NO & NO & D: idioms \\
\hline
\end{tabular}




\section{Myriam Bouveret}

Categories B and C are very close: they both characterize semi-fixed expressions, but B is limited to the support verb category. The necessity to set apart a category $\mathrm{C}$ is sustained by the fact that corpus results attest either to lexically-constrained semi-idioms (donner le sein 'to breastfeed', donner la becquée 'to feed', donner le biberon 'to give the bottle') or grammaticallyconstrued expressions, for example, the case of ' $\mathrm{X}$ donne $Y \grave{a}+$ predicate', as seen in section 4. Idioms classified in D are ranked last in the corpus (donner la chair de poule 'give goosepimples', donner du fil à retordre 'give a hard time', ne plus savoir où donner de la tête, en donner pour son argent 'give someone their money's worth').

\subsection{Support Verbs and Lexical Functions}

Meaning structures in the Meaning-Text theory are classified as either pragmatic or semantic. Semantics-bearing units are divided into three types: semi, quasi, and full phrasemes, depending on the fixity of their relationship with form. We describe here the semi phraseme, that is to say, the lexical functions (LFs), and amongst those, the specific lexical functions encoding collocations of support verb constructions. "A lexical function is a function that associates with a specific lexical unit (L) which is the argument or 'keyword' of $f$, a set of synonymous lexical expressions, the value of $f$ " (Mel'čuk 1998:32). There are about sixty simple standard LFs in addition to complex LFs and non-standard LFs or configurations. Lexical functions encode a set of syntagmatic and paradigmatic semantic relations between lexical units. Syntagmatic lexical functions are, amongst others, modifiers, support verbs, realization verbs, phasal verbs, causation meanings. Paradigmatic lexical functions map between lexical classes for example from events to instruments, results, or medium. Morphologically they often involve derivation, e.g.: to depart, departure. A lexical function takes into account meaning components of the definition. The LF [Magn] for example means 'magnitude of the entity' and is restricted to applying to gradable concepts. The contrast between high fever ('forte fièvre') and heavy rain ('forte pluie') in English shows that the same LF can be instantiated in different lexical items: high fever (Eng.) = forte fièvre (Fr.); heavy rain (Eng.)= forte pluie (Fr.).

A support verb LF is a lexical rule mapping the semantic level to the syntactic level. Support verbs LFs are [Oper, Func, Labor] . Each verb is established in relation to the syntactic role of the lexical unit in the verbo-nominal construction, subject, object, indirect object, as these are linked to their deep syntactic actants I, II, and III. The function [oper], for example, is used for a support verb object construction, the LF links at the deep syntactic level a deep syntactic actant of $\mathrm{L}$ to $\mathrm{L}$ itself. Actant 1 is an agent, actant 2 is an object or theme, and actant 3 is a recipient or goal. oper is indexed with the number of the actant which turns up as a subject in the resulting construction.

Oper1 (order) $=$ give

Oper3 $($ aid $)=$ receive 


\title{
GIVE Verb-Object Constructions in French from Grammar to Idioms
}

\author{
Oper13 $($ resentment $)=$ feel $[\sim$ about $N]$ \\ Funco $($ snow $)=$ fall \\ Func2 (blow) $=$ fall [upon N] \\ Labor12 (interrogation $)=$ submit $[N$ to an interrogation]
}

Support verb LFs also appear in complex LFs or configurations of LFs as in Magnoper $($ war $)=$ rage on .

\section{A Case Study of $X$ DONNER $Y+$ Infinitive}

We will now study the particular case of a semi-fixed grammatical construction which has several occurrences in the corpus. It is not a frequent construction but the pattern is striking since it appears in completely fixed expressions, semi-fixed expressions or free constructions: X DONNER $Y+$ Infinitive as in donner du grain à moudre 'give material for conversation', donner (matière) à penser 'give someone something to think about', donner une énigme à résoudre 'give a riddle to solve'.

\subsection{Evidence for Constructionality?}

"A construction (e.g. the subject-auxiliary construction) is a set of conditions licensing a class of actual constructs of a language (e.g. the class of English inverted clauses (...)" (Kay and Fillmore 1999:3). A construct however does not have to be fully regular or predictable, but constructions can be grouped into a family by partial similarities. For Langacker (1991), a construct is a grounded conceptual entity. I examine here this notion of groundedness, looking at grammatical, semantic, cognitive, etymological/morphological evidence in a case study of the transitive construction DONNER + Infinitive.

In French, the construction X DONNER Y $\grave{a}+$ Infinitive (à Z) is trivalent but a two or three argument complementation is encountered:

- Donner du fil à retordre (loc. 1680), 'give a hard time', literally: 'give a rope to twist' Mon cocker me donne du fil à retordre (forum Feminin.com, September 19, 2007)

- Donner du grain à moudre 'give material for conversation', literally: 'give grain to grind' L'assassinat de Bhutto donne du grain à moudre aux candidats US (Le Monde, December 29, 2007)

- Donner matière à penser 'give someone something to think about' Enfin, cette collection donne matière à interrogation portant sur la question de la ... Elles donnent matière à penser à partir des textes de philosophes ... (EspaceTemps.net, 2004)

- Donner des devoirs (à faire) /donner à faire des devoirs 'give homework'

- Donner ses chaussures à ressemeler 'give one's shoes for re-heeling', sa montre à réparer 'one's watch for repair'

- Donner une énigme à résoudre 'give someone a riddle to solve'

Should we consider in this construction the infinitive clause as simply adding a compositional purpose meaning to the main clause? Semantic evidence of a more construed meaning is provided with the existence of a GIVING frame (a 


\section{Myriam Bouveret}

Donor transfers a Theme from a Donor to a Recipient) activated through the trivalence: X (agent) GIVE Y (theme) [to $+\mathrm{V}$-ed] to Z (recipient/patient). This frame is present in several sentences when the object $Y$ is effectively transferred from $\mathrm{X}$ to $\mathrm{Z}$, the third argument being effectively present or not in the sentence as in give one's car for repair. In this frame, the infinitive clause refers to the Purpose. $^{7}$ The purpose, however, cannot be any purpose: give one's car for repair sounds perfectly normal but \#give one's car to destroy sounds unusual. The purpose then in the sentence has to realize some event associated with the theme in a conventional frame, which can be paraphrased: $\mathrm{X}$ causes $\mathrm{Z}$ to perform $\mathrm{W}$ activity (literal or metaphoric), $\mathrm{W}$ activity being a realization of what has to be accomplished with object $Y$.

But the GIVING frame does not explain the whole meaning of the construction, a REQUEST frame seems dominant. Grammatical evidence for this can be found in the fact that the $a$ complementation in this construction is either an infinitive or a predicative noun: donner ses chaussures à ressemeler 'give one's shoes to be re-soled', donner sa voiture au lavage 'give one's car to the carwash', donner sa voiture au contrôle technique 'give one's car for checking'. In several sentences the notion of transfer is not activated, but the frame REQUEST ${ }^{8}$ is activated: le professeur donne des devoirs (à faire) aux élèves 'The teacher is giving homework to the pupils'. In this frame a Speaker asks an Addressee for something, or to carry out some action. Synonyms activating the same frames are ask, order, request, i.e. the dominant frame in X DONNER $Y+$ Infinitive is then a REQUEST one: $X$ REQUEST $Z$ to perform an activity $\mathrm{W}, \mathrm{W}$ (activity) being a typical realization of $Y$ (theme).

Deep semantic evidence of this meaning is provided with the semantic role of addressee assigned to the third argument in the construction with a REQUEST frame instead of - or in addition to - the role of recipient in a single GIVING frame. In the following sentence (5), for example, the argument structure is composed of an agent, a theme, a recipient-addressee and a purpose:

Le professeur donne un livre à lire aux enfants.

'The teacher asks the children to read a book.'

Les enfants se sont vus donner un livre à lire par le professeur.

'The children were given a book by the teacher.'

Les enfants doivent lire le livre indiqué par le professeur.

'The children have to read the book indicated by the teacher.'

Les enfants doivent lire le livre que le professeur a indiqué.

'The children have to read the book indicated by the teacher.'

\footnotetext{
7 FrameNet, Frame Report created by infinity on Sat Jun 23 .20:15:16 PDT 2001, http://www.framenet.icsi.berkeley.edu

8 FrameNet, Frame Report created by wooters on Wed Feb 07 16:12:03 PST 2001. http://www.framenet.icsi.berkeley.edu
} 


\section{GIVE Verb-Object Constructions in French from Grammar to Idioms}

Paraphrase (6) of the sentence highlights the addressee role of the third argument in the passive alternation. The modal auxiliary doivent in sentence (7) shows the existence of a secondary agent causally affected by the act of giving. Notice that there is a close parallel to (7), (8), which clearly uses a verb of information rather than one of giving. This informational frame is also evoked in a variation of the construction where the theme can only be postponed to the infinitive clause, e.g. il nous a donné à entendre qu'il était mécontent 'he let us know that he was not satisfied'.

In the more central X DONNER Y (noun) $\grave{a}+$ Infinitive construction, an infinitive clause or a predicative noun can be introduced with the preposition $\dot{a}$. In the case of a noun, this argument is assigned the semantic role of a goal including the purpose. For example, donner ses chaussures au cordonnier 'give one's shoes to the cobbler' implies the purpose 'to repair', whereas donner ses livres au cordonnier 'give one's books to the cobbler' does not make it possible to imply a purpose so that the meaning of a GIVING frame is activated. This meaning is construed by the verb + concrete object construction; the third argument $\mathrm{Y}$ if present, is assigned a semantic role of recipient instead of the addressee role activated in the REQUEST frame.

Looking at Etymology provides traces of a REQUEST frame in French shared by the two verbs donner and ordonner. Donner as a concrete meaning emerges in Les serments de Strasbourg (842). Ordonner (1119) means first 'put in order' and ordonner 'give an order' appears in 1165 . In 1200, a phonetic contamination is supposed between ordonner and donner, since the Latin form ordinare had evolved in *ordinner but the proximity with the existing donner influenced the actual form ordonner. Verbal phrases with donner and ordonner, e.g. donner $\grave{a}$ entendre 1269, 'cause to listen', donner l'ordre de payer 1590 'order a payment', ordonner un médicament 1558 'give a prescription', show an overlapping of meaning between the two verbs particularly in the morphological derivation, donner and ordonner both sharing the capacity to express causation and order.

In conclusion, $X$ GIVE $Y \grave{a}+$ Infinitive is not strictly a grammatical construction neither does the infinitive clause simply provide a compositional meaning of purpose. We have proved so far that this construction shows a specificity that can be called, following Jackendoff 2008, a 'syntactic nut'.

\subsection{Causation in DONNER}

According to Ruwet (1972), donner in French includes a causation meaning (see 9a, 9b). A decomposition into a complex event involving causation is proposed by Goldberg in a CAUSE MOTION type of event (see 9c, 9d):

a. Stephane a donné le livre à Arthur. 'Stephane gave the book to Arthur.'

b. 'Stephane a fait avoir le livre à Arthur' (Ruwet 1972:152).

c. Sam gave his car to the church (Goldberg 1995, 2007).

d. 'X CAUSE MOTION of Y from X to Z' 


\section{Myriam Bouveret}

The causation in the $X$ DONNER $Y \grave{a}+$ Infinitive construction exists as a continuity between a weak meaning of a factitive 'cause to' in (10) and a strong meaning of request in (12), and a weaker one would be possible as well in (11):

(10) Il nous donne à entendre que la situation est délicate. 'He let us know that we are facing a delicate situation'.

(11) Paul a donné son article à relire à Jean. 'Paul asked Jean to read his paper'. (12) Ils sont partis en nous donnant la vaisselle à faire. 'They told us to do the dishes as they left'.

In conclusion, $X$ DONNE $Y+$ Infinitive is a factitive construction, where donner behaves like a factitive semi-auxiliary close to other French semiauxiliaries laisser $\grave{a}+$ predicate, faire + predicate. This donner factitive construction either completely hides the central concrete GIVING meaning but activates a weak CAUSATION meaning or a strong REQUEST meaning or renders both events of 'transfer' and 'request' present at the same time. A third frame of INFORMATION can be present, attested in the main construction or in a less central variation of the construction with a Y clause. The meaning of the $X$ DONNER $Y$ + Infinitive construction is then the following: $\mathrm{X}$ (agent) CAUSE $\mathrm{Z}$ (recipient OR addressee) to receive $\mathrm{Y}$ (object OR information) and to do $\mathrm{W}$ (action), $\mathrm{W}$ being a typical realization of what can be accomplished with Y.

\section{Conclusion}

There are collocational, semantic, syntactic, and morphological regularities allowing the recognition of families of constructions even among highly lexicalized idioms such as donner du fil à retordre 'to give a hard time' which can be related to other expressions sharing the same pattern and meaning, that is to say, a construct. Although the notion of construction has been proved in literature to be usage-based, cognitive salience seems to be as important as frequency in a case study unrelated to language acquisition. We have established in the case of the $X$ DONNER $Y+$ Infinitive construction that the recognition of this construct is linked to a cognitive salience manifested in lexical, syntactic, semantic, pragmatic, cognitive clues allowing the recognition of the construction as a whole.

Where should we encode constructions in a lexicon? For idioms like donner du fil à retordre 'give a hard time', for example, neither the meaning implied by the construction itself nor the meaning of any of the lexical units helps us to understand correctly the meaning of this fixed idiom. It is necessary to create a lexical entry for a completely fixed idiom (category D in Table 2, section 3.1.). In the case of a semi-fixed construction such as $X$ DONNER $Y+$ Infinitive (category $\mathrm{C}$ in Table 2, section 3.1.), e.g. donner sa voiture à réparer 'give one's car for repair', a notation (+ causal relation) might be added to the construction encoded under donner verb entry linked to the appropriate frame(s). In the specific case of 


\section{GIVE Verb-Object Constructions in French from Grammar to Idioms}

the semi-fixed constructions with support verbs (category B in Table 2, section 3.1.), e.g. donner un conseil 'give advice', the construction has to be described under the noun entry, linking the support verb to the noun as a direct object activating the appropriate frame.

This paper has illustrated the proximity between lexicon and grammar: it is the syntax-semantic interface that makes it possible to construe the meaning of the verb object construction, in particular with support verb constructions. Most of all, a construction is a cognitive entity expressing relations of cognitive salience: meaning has proved to be grounded in our case study, and the process of connecting pieces building the construction as a whole is essential.

\section{References}

Analyse et Traitement Informatique de la Langue Français. 2007. Dictionnaire étymologique, Centre National de Ressources Textuelles et Lexicales, Centre National de la Recherche Scientifique http://www.cnrtl.fr/etymologie/donner, accessed January 15, 2008.

Bouveret, Myriam, and Charles J. Fillmore. 2008. Verbo-nominal Constructions in FrameNet Matching Lexical Functions in MTT. Proceedings of the XIIIth Euralex Congress, Barcelona July 15-19, 2008, European Association of Lexicography.

Goldberg, Adele. 1995. Constructions. Chicago: The University of Chicago Press.

Goldberg, Adele. 2006. Constructions at Work. The Nature of Generalization in Language. Oxford: Oxford University Press.

Goldberg, Adele, and Devin Casenhiser. 2006. Learning Argument Structure Constructions. In E. Eve Clark and Barbara F. Kelly, eds., Constructions in Acquisition, 185-205. Stanford: Center for the Study of Language and Information.

Gross, Gaston. 1989. Les constructions converses du français. Genève-Paris: Librairie Droz.

Gross, Gaston. 2005. Introduction. Linguisticae Investigationes 27(2):167-169. Amsterdam: John Benjamins Company.

Jackendoff, Ray. 2008. Construction after Construction and its Theoretical Challenges. Language 84(1):8-28.

Kay, P. and Charles J. Fillmore. 1999. Grammatical Constructions and Linguistic Gneralizations: The What's X Doing Y? Construction. Language 75:1-34.

Koenig, Jean-Pierre. 1993. Linking Constructions vs. Linking Rules: Evidence from French. Proceedings of the 19th Annual Meeting of the Berkeley Linguistics Society, 217-231. Berkeley, CA: Berkeley Linguistics Society.

Langacker, W. Ronald. 1991. Foundations of Cognitive Grammar, Vol. II: Descriptive Applications. Stanford: Stanford University Press. 
Myriam Bouveret

Langer, Stefan. 2004. A Linguistic Test Battery for Delimiting Support Verb Constructions. Linguisticae Investigationes 27(2):171-184. Amsterdam, New York: John Benjamins Company.

Levin, Beth, and Malka Hovav Rappaport. 2005. Argument Realization. Cambridge: Cambridge University Press.

Mel'čuk, Igor. 1997. Vers une linguistique Sens-Texte. Leçon inaugurale. Paris: Collège de France.

Mel'čuk, Igor. 1998. Collocations and Lexical Functions. In A. Cowie, ed., Phraseology: Theory, Analysis and Applications, 23-53. Oxford: Clarendon Press.

Mel'čuk, Igor. 2005. Verbes supports sans peine. Linguisticae Investigationes 27(2):203-217. Amsterdam, New York: John Benjamins Company.

Ninio, Anat. 1999. Pathbreaking Verbs in Syntactic Development and the Question of the Prototypical Transitivity. Journal of Child Language 26:61953.

Piñango, Maria Mercedes, Mack, Jennifer, and Ray Jackendoff. 2006. Semantic Combinatorial Processes in Argument Structure: Evidence from Light Verbs. Proceedings of the 32nd Annual Meeting of the Berkeley Linguistics Society. Berkeley, CA: Berkeley Linguistics Society.

Ruwet, Nicolas. 1972. Théorie syntaxique et syntaxe du français. Paris: Editions du Seuil.

Sag, Ivan A., Timothy Baldwin, Francis Bond, Ann Copestake, and Dan Flickinger. 2002. Multiword Expressions: A Pain in the Neck for NLP. In Proceedings of the Third International Conference on Intelligent Text Processing and Computational Linguistics (CICLING 2002), 1-15. Mexico City, Mexico.

Sweetser, Eve. 1990. From Etymology to Pragmatics, Metaphorical and Cultural Aspects of Semantic Structure. Cambridge: Cambridge University Press.

Žolkovskij, A.K., and Igor Mel'čuk. 1967. A. O semantičeskom sinteze — Sur la synthèse sémantique. In Problemy kibernetiki 19:177-238. [Three translations of the paper exist: a. in Hungarian: Dokumentació és nyelvészet, Budapest, 1969, 61-176; b. In English: Systems Theory Research, N.Y., v. 19; c. In French: T.A.Informations, 1970, ${ }^{\circ}$ 2, 1-85.]. Librairie Klincksieck.

Myriam Bouveret

University of Rouen

Department of Linguistics

7 rue Thomas Becket

76180 Mont-Saint-Aignan, France

myriam.bouveret@univ-rouen.fr

bouveret@berkeley.edu 